\title{
Identifiying Digital Literacy of High School Students: A Case of Hendek*
}

\section{Kaan ARIK ${ }^{* *}$}

\author{
Mübin KIYICI***
}

\begin{abstract}
This research aims to identify digital literacy level of 10 th grade high school students' and determine those levels in terms of different variables. In this study, the research method was performed according to the relational comparing model as a comparison type. The research population consists of 948 students from all high schools in the province of Hendek at Sakarya in 2016-2017 education season year. And the sampling consisted of 394 students from 5 different high schools. Digital Literacy Scale that translated to Turkish by Hamutoğlu, Güngören, Uyanık and Erdoğan (2017) was used in this research for data collection tool. Personal information section was added by reseacher to scale. Standard deviation, frequency analysis, arithmetic averages, descriptive statistical data, one-way analysis of variance (ANOVA) and independent sample t-test techniques was used to analyze research. The level of high school students' digital literacy; doesn't vary according to having a personal mobile Internet connection for regular use, the type of university exam scores gets into university exam score, family economic income, active time period on Internet. But gender, having a personal computer for regular use varies according to technical sub-dimensional and active time period on personal computer varies according to technical, cognitive and social dimensions.
\end{abstract}

Keywords: Digital, literacies, digital literacy, high school students

\footnotetext{
* This study was compiled from the master thesis entitled " Identifiying digital literacy of high school students".

** Orcid ID: https://orcid.org/0000-0002-0930-8955, Ress. Assist., Beykoz University, Department of Digital Game Development, kaanarik@beykoz.edu.tr

*** Orcid ID: https://orcid.org/0000-0001-9458-7831, Assoc. Prof. Dr., Sakarya University, Faculty of Education, Department of Computer Education and Instructional Technologies, mkiyici@sakarya.edu.tr
} 


\section{INTRODUCTION}

The world in which we are is also evoking millions of symbolic narratives as well as written texts. While people try to understand each other, they are also aware of what is going on around them. Sometimes during the transfer process, while transferring situations to each other, people need writings to express themselves better (Altun, 2008). In this respect, the concept of literacy has gained value and has taken its place in this process. Skills such as comprehension, narration, and awareness have been shaped by the most basic meaning of literacy. In order to define literacy, scientists concentrated on academic studies and contributed to the emergence of literacy in theory and practice through emerging studies in 20th century. Fransman (2006) stated that researchers have a comprehensive discipline of literacy, as well as a controversial research topic by scientists working in fields such as psychology, economics, linguistics, sociology, anthropology, philosophy and history.

UNESCO (1970) stated that literacy consists of skills such as bonding, learning and deducing between previous learning and subsequent learning. The literacy of literary experts has not been able to provide a specific view on the subject because reading and writing activity for some people is considered as linguistic skills among some individuals (Adams, 1993). Cope and Kalantzis (2000) stated that they do not only have the ability to analyze and understand words, but also include the ability to interpret signs, symbols, photographs and sounds that vary in social content. In this respect, reading and writing skills, it also determines the capacity of subsequent learning. In the same vein, Prenksy (2001) stated literacy as separation of the unknown. Literacy, which is an indispensable tool for active participation in daily life in terms of the social and economic structure of the 21st century, also have a important place in basic education.

According to customs and smart phones survey by the Ministry of Customs and Trade of Turkish Republic, automobile and food consumption in the report is the ratio of smartphone usage rate has reached 84 percent in Turkey (Cumhuriyet, 2017). In the remaining part, the rate of telephone use was 14.7 percent and the number of nontelephone users was 1.3 percent. It is not enough in terms of the development of technology that only smartphone usage research can realize how important technology is in our daily lives. The technologies that we can use in daily life can be listed as follows. Personal computers, tablets, console devices and wearable technologies are some of these technologies.

\section{Purpose}

The aim of this study is to determine the digital literacy levels of 10th grade high school students in Hendek district of Sakarya and to examine the digital literacy levels in terms of various variables. Also, it is aimed to facilitate future studies as the study tries to measure the levels of digital literacy. 


\section{Literature}

With the emergence of the concept of lifelong learning, literacy has become more comprehensive and local libraries have been included in this process. In Turkey, national researches and projects have been increased in the field of lifelong learning and literacy combined with library services (Ministry of National Education of Turkish Republic, 2007; 2008; 2009). Those projects are listed in below.

Projects;

- Adaptation of Media Literacy course to all education through institution,

- Producing and presenting projects related to information access centers and learning centers,

- Determining teacher and student qualifications.

- Presentation of information and internet literacy trainings on a project basis,

- Development of portal applications related to education,

- Effective use of Web 2.0 content in education,

- Preparing a digital library and developing these library projects.

\section{Digital Literacy}

While a number of theories and practices on literacy have continued, the emerging technology has introduced concepts such as computer literacy, technology literacy, scientific literacy, network literacy, media literacy, and digital literacy. With the invented of the electronic circuit computer in the period after 1945, a digital age change has started and this change has been rapid. This change has brought different technologies together with the widespread use of computers.

Shortly thereafter, in 1989, Tim Berners Lee developed the HTML language and WWW (World Wide Web) system for use in CERN labs. With the development of the WWW structure, the current web page was 50 in 1992, and in 1996 this number exceeded 40 million (Science and Technology for All, 2017). In the 1990s, portals, sites and commercial-themed networks began to emerge, and the first social networks, blogs, wikis and online courses were created in the millennium as the development of the Web 2.0 system. Such ongoing technology has included other devices such as smartphones, tablets and touch devices (Palfrey and Gasser, 2008).

Street (1984) also implied that literacy is optimal remembered (optimal understood) from the concepts derived from reading and writing skills. That definition supports the idea that the concept of digital literacy can be associated with the concept of basic literacy. Therefore, Gilster (1997) stated that digital literacy has the ability to understand and use the information presented in the computer in different formats. It is possible to say that the usage of information and communication technologies towards 
the 2000s increased in our daily life. Accordingly, literacy concepts were differentiated within the scope of knowledge and skills and various definitions were made.

Eshet-Alkalai (2002) defines digital literacy as a set of cognitive, psycho-motor, and socio-emotional skills not only to use a digital device or software, but also to enable it to efficiently perform its daily tasks in digital environments. Accordingly, digital literacy is the ability to see the difference between definitions based on a self-generated concept rather than standardized presets (Lankshear and Knobel, 2006). Tornero (2004) defined digital literacy as the ability to use information and information technologies. Digital literacy is more sophisticated and built-in practices in generating, understanding and communicating meaning and knowledge in the digital world through information and communication technologies (Future Lab, 2010).

Kiyıcı (2008) stated that in the 21st century, it is a set of technological knowledge and skills that people need to adapt their lives within the framework of lifelong learning activities and to create useful ideas for the society in which they live. According to Appel (2012) digital literacy is the ability to research and analyze information acquired through the use of WEB and computer. In addition, Hagel, Horn, Owen and Currie (2013) emphasized that digital literacy is considered as one of the key literacy links that accelerates learning and understanding capacity.

Meanwhile -please be reminded- that skills such as reaching and analyzing information are processed within the scope of knowledge literacy skills. In other words, it is the ability of the individual to acquire basic practical skills in order to become fully competent in the information society. In this context, the importance of personal development of the individual in the information society is emphasized. According to Sharma, Fantin, Prabhu, Guan and Dattakumar (2016), they stated that based on the above definitions, they had the ability to use digital media to create a content and to use the internet and new media to critically evaluate it. Looking at these skills, the concept of digital literacy in information society is one of the leading literacy.

\section{Importance of Digital Literacy}

It is undoubtedly a fact that the Internet is considered a very frequently used tool in everyday life. However, this development process has brought some advantages and obstacles. It has adapted students to readiness to access information and has become an obstacle to the process of production of knowledge. Rimer (2003) stated that 38\% of the students in secondary education in a certain region of America increased plagiarism by copy and paste method. After a while, in a study conducted by Evering and Moorman (2012), the researcher reported that $34 \%$ of school students in the study area of the researcher used the information in the same way from the internet, and 52\% stated that they used the information without taking bibliography by taking the information completely via internet. When we look at the studies, it can be said that scientific ethic values are not observed in the use of information and this element has a preventive role in the production of new knowledge. These statistics show that students' tendency to 
find information is also dependent on Web technology in the context of a primary source of information to gather information outside the school environment. Research has indicated that, despite the frequency of technology tools, students lack insufficient knowledge literacy skills and lack of critical thinking skills (Oblinger, 2005). One of the skills that people should have in this subject is the ability to follow the ethical rules in the scientific writings that are considered within the scope of digital literacy and the social dimension of this concept.

\section{Digital Literacy Skills}

While searching for information in different sources in the 1990s was considered a complex action, it is now possible to find information on a single platform without the need to reach individual sources separately. In the 1990s, the skills that are expected to be acquired by individuals within the scope of digital literacy have changed over time. Gilster (1997) defined digital literacy as the ability to use data in the context of ethical rules in the presence of internet connection. While talking about these skills, he stated that in addition to having an internet connection, he / she covers daily life skills such as being familiar with and using technological devices, preparing a report in word processing software and having online / real time shopping activities.

Kavalier and Flannigan (2006) also emphasized that in a society that has reached a technological position, new generations should have basic level digital competence to be effective in the digital world. Akkoyunlu and Soylu (2010) stated that there are various components of technology such as internet, e-mail, smart devices, camera, video, web technology and social media which provide the possibility of transmitting and storing information in digital environment. Kazu and Erten (2014) stated that an individual who is a digital literate covers the ability to effectively reach, use, evaluate and present the information to be produced. Ng (2012) stated the basic skills that a digital literate should perform. A digital literate individual can do;

- Develops basic level computer skills and provides access to the necessary resources in daily life,

- To conduct research, access to information becomes effective, definitions and evaluates,

- Attitudes towards online ethics rules,

- When faced with any technical problem, he/she can produce practical solutions.

- Keeps itself away from potential harmful situations in digital environments.

Eshet-Akalai (2004) examined digital literacy in five sub-dimensions. These literacy are described under five literacy types, photo-visual, reproduction, branching, information and socio-emotional literacy, which are required to define the concept of digital literacy. However, by reviewing this model in the following process, was added six sub- 
dimensions to the existing five sub-dimensions by adding un real-time thinking skills un sub-dimension.

Within the scope of digital literacy is as follows:

- Photo-Visual Literacy: Ability to make sense of the content coming through the media and use it for its own benefit. Messages in visual or graphic messages are included in this group.

- Reproducing Literacy: Ability to produce new knowledge by reinterpreting the acquired information in digital environment. In this process, the individual has not only understood the texts but also the data from the media and online media.

- Branching Literacy: Ability to reach information through different sources, to understand the different information obtained, to extract the wrong information and to link it to a conclusion. Thus, it is not static and the possibility of development by other users increases.

- Information Literacy: Ability to use the information that is reached and / or produced through the media or online resources to convey the information to different users, to structure the information according to the inductive method, in other words by combining the small pieces into a whole and using it.

- Socio-Emotional Literacy: It's the reaction of the people against the data coming from digital environments. People can encounter all kinds of data in a virtual environment. Also using constantly developing technology face some problems in this process. Socio-emotional behaviors are indicated as the attitude towards this problem. For example, while searching for information on the internet, an ad may appear and people can't realise whether or not. The individual's socioemotional skills are behavior that he demonstrates against the realism of this ad.

- Real-Time Thinking Literacy: It is the state of having a special thinking ability which is intended to be explained by the real-time thinking skills of today's digital media users. Although this concept is not recent, it is the process of thinking and syncing the information at the same time in order to obtain information. The individual must be able to process the information coming from the digital environment instantly and develop solutions for the application if they face any problems. In this process, besides developing the thinking skills of the individual, the ability to adapt to daily life takes place.

Aviram and Alkalai (2006) reported the cognitive, technical and socio-emotional dimensions of digital literature in the definition of literature in single or multiple dimensions. Basically, digital literacy based on technical skills, cognitive and environmental impacts are also influenced by socio-emotional dimensions (Alkalai, 2004). 


\section{Dimensions of Digital Literacy}

As mentioned above, digital literacy is handled in three dimensions. These studies support the cognitive, technical and socio-emotional aspects that Ng (2012) explains. Ng (2012) examined the theoretical framework of digital literacy in three dimensions. These dimensions;

- Cognitive,

- Technical,

- Socio-emotional.

\section{Cognitive Dimension}

An individual with a digital literacy can choose the most appropriate method to solve the problem in the learning process or use this method effectively in their daily work. Also he/she can download or purchase a free graphic design program to draw a geometric object or a diagram. However, in MS Word, he/she can use SmartArt to do what is desired. Here, the individual follows the steps of selecting and evaluating the appropriate programs to be learned by bringing individuality to the forefront. Thus, has chosen the most appropriate function to solve the problems he/she has encountered or has produced different methods to achieve this.

\section{Technical Dimension}

Regardless of teacher or student distinction, the digital literate person must be able to perform basic computer skills and fulfill the required knowledge. An individual with a basic digital readout should be able to establish a functional connection between the computer and the device in the event of a problem. For example, these are basic terms associated with switching the Bluetooth or Infrared feature on / off, downloading or sending data, using social networking tools, sending or receiving e-mails, and the user interface. In a number of similar cases, a digital literate individual can regularly update anti-virus programs to avoid viruses and unwanted spam and convert it into a process of literacy. Also he/she can read the manual in the face of any problems you encounter, or watch a video about the problem through YouTube.

\section{Social Dimension}

Web 2.0 technology to send e-mail to access the internet connection, photo sharing, games, video and music downloads, blogs and wikis writing skills such as a young people are considered to be a way of life. These skills provide learning to collaborate with online communities on Web 2.0. For example, contributing to the blogs where scientific researches are conducted and their discussions, and evaluating the information coming through written texts, videos or images according to their own criteria are evaluated in this dimension.

The social dimension skills of a digital literate individual are as follows: 
- An individual takes care to use appropriate language and words to prevent misunderstanding of the information he/she has reached and to express himself / herself,

- Has a knowledge about Netiquette (rules of ethics in the Internet),

- Keeps personal information as private as possible and protects your own security and privacy.

\section{Problem}

High school students participating in the research;

Sub-problem - 1) What is the digital literacy level of high school students participating in the research?

Sub-problem - 2) Does digital literacy levels of high school students differentiate according to;

- Age,

- Gender,

- Point type of university exam,

- Having a personal computer status,

- Time elapsed on a computer,

- Active time elapsed on the Internet,

- Economic income level of the family,

- The availability of 3G / 4.5G mobile Internet connection on the phone variables.

\section{METHOD}

A descriptive survey model was used to determine the high literacy levels of high school students. The descriptive survey model is chosen to present a situation related to the problem of interest within the scope of the research (Büyüköztürk, Akgün, Karadeniz, Demirel and Çakmak, 2017). The other reason for using descriptive survey model in the research is that it requires to collect data in order to test hypotheses about the current situation related to research subject and to answer the questions.

\section{Population-Sample}

The research population consists of 10th grade students in high schools determined by the researcher. The research was carried out by purposeful sampling method from nonrandom sampling because of the lack of access to all high school students in the district. Objective-based sampling method is based on the goal of the study. It is preferred in case 
of working with one or more groups that meet certain criteria or which have certain characteristics (Büyüköztürk, Akgün, Karadeniz, Demirel and Çakmak, 2017).

10th grade students in the study because of the sample because of the 9th grade students' process of adaptation, and for 11-12 grades the university exam process in the period of education, as well as not being able to fully express itself in different concerns. 455 students from 5 high schools were reached during the sampling process. The response of 61 people in the data entered was not found in the analysis because the scale was not suitable for the response of the scale. The research population consisted of 948 students from all high schools studying in the 10th grade in the city of Hendek in the province of Sakarya in the academic year 2016-2017, and the samples were 394 students from 5 different high schools. Data were collected from 5 different high schools, Akşemseddin Technical High School, Osmangazi Technical High School, Hendek High School, Atike Hanım High School and Hendek İmam Hatip High School.

\section{Data Collection Method}

Digital Literacy Scale, which is used as a data collection tool, is the sum of the 4 subdimensions which include the original attitude, cognitive, technical and social subdimension. The validity and reliability study of the scale was conducted by Hamutoğlu, Güngören, Uyanık and Erdoğan (2017). Sub-dimensions of the scale were taken in the same manner and a translation study was conducted by 3 experts from English to Turkish and then from Turkish to English. Then, two forms were applied by 37 academicians, who knew Turkish and English, and the correlation coefficient between the two forms was determined significantly. Digital literacy scale A 5-point Likert-type rating was determined in the form of Strongly Agree (5), Strongly Disagree (1). The scale is composed of 17 items. Ingredients attitude size, 7.-13. Technical specifications of materials, 13.-15. substances cognitive dimension and 15.-17. substances measure social dimension. The reliability coefficient of .70 and above is considered reliable (Köklü, Büyüköztürk and Bökeoğlu, 2012). According to this, it is possible to say that all of the "Digital Literacy Scale" and the attitudes, technical, cognitive and social sub-dimensions of reliability coefficients are sufficient (Büyüköztürk, Akgün, Karadeniz, Demirel and Çakmak, 2017).

\section{Analysis of Data}

In the research process, data from the data collection tool were analyzed by the high school students in the schools determined before the analysis of the data obtained from the data collection tools were collected from 1 to 394. The data obtained after the enumeration were transferred to the computer. After the transfer of data to computer environment, arithmetical average of the questions about high school students' digital literacy and sub-dimensions, attitude, technical, cognitive and social sub-dimensions were taken. After this stage, the normality test was conducted for the purpose of shaping the research according to the desired result and the analyzes were performed according to the assumption that the data were distributed normally. In the one-way analysis of 
variance, if the $\mathrm{F}$ value was significant, LSD from the post-hoc tests was used to determine that there was a significant difference between some mean values (Köklü, Büyüköztürk and Bökeoğlu, 2007).

A single sample Kolmogorov-Smirnov (one-sample KS) test was used to determine whether the total scores obtained from the digital literacy scale showed normal distribution, and shaped as normal distribution $(z=, 878 ; p>, 05)$.

As a result of the analysis of the data, the skewness value was determined as ,376, and the kurtosis value was determined as ,166. Due to curtosis and skewness values between $-1,5$ and $+1,5$, it can be said that the data was distributed normally (Tabachnick and Fidell, 2013).

The data collected through the scale applied to the high school students who participated in the study were analyzed with digital literacy and 4 sub-dimensions. Independent samples t-test was applied in order to determine whether high school students' gender, personal computers, personal internet connection, and mobile internet connection variables. ANOVA and Independent Samples t Test was used in order to understand whether variables differ or not.

\section{FINDINGS}

Table 1.

Frequency Distribution and Meanings of High School Students by Demographic Characteristics

\begin{tabular}{|c|c|c|c|}
\hline Variable & & $\mathrm{f}$ & $\%$ \\
\hline \multirow{2}{*}{ Gender } & Male & 156 & 39,6 \\
\hline & Female & 238 & 60,4 \\
\hline \multirow{4}{*}{ Point Type of University Exam } & $\mathrm{A}$ & 115 & 29,2 \\
\hline & $\mathrm{B}$ & 57 & 14,5 \\
\hline & $\mathrm{C}$ & 193 & 49 \\
\hline & $\mathrm{D}$ & 29 & 7,4 \\
\hline \multirow{2}{*}{ Status of Having a Personal Internet Connection } & Yes & 174 & 44,2 \\
\hline & No & 220 & 55,8 \\
\hline \multirow{2}{*}{$\begin{array}{l}\text { Status of Having a Personal Mobile Internet } \\
\text { Connection }\end{array}$} & Yes & 363 & 92,1 \\
\hline & No & 31 & 7,9 \\
\hline \multirow{7}{*}{ Time Elapsed on Computer Using } & None & 136 & 34,5 \\
\hline & 1-3 Hours & 201 & 55,8 \\
\hline & 3-5 Hours & 33 & 8,4 \\
\hline & - & 14 & 3,6 \\
\hline & 5-7 Hours & 7 & 1,8 \\
\hline & 7-12 Hours & & 0,8 \\
\hline & 12 hours and upper & & \\
\hline
\end{tabular}




\begin{tabular}{llll}
\hline & None & 11 & 2,8 \\
& $1-3$ Hours & 171 & 43,4 \\
Activition Time Elapsed on Internet & $3-5$ Hours & 108 & 27,4 \\
& $5-7$ Hours & 51 & 12,9 \\
& $7-12$ Hours & 33 & 8,4 \\
& 12 hours and upper & & \\
\hline Family Economic Income Levels & $0-1440$ TL & 87 & 22,1 \\
& $1440-2000$ TL & 119 & 30,2 \\
& $2000-3000$ TL & 97 & 24,6 \\
& $3000-4000$ TL & 58 & 14,7 \\
& 40000 TL and & 33 & 8,4 \\
\hline
\end{tabular}

Students in high school are prepared in 4 different score types in Turkey for the university exam. These types of scores are evaluated by taking into account (A) mathematics and science, (B) literature and social sciences, (C) both mathematics and social sciences, and (D) foreign language proficiency.

According to the answers given to the digital literacy scale of high school students participating in the research in Table 1;

- 156 (39.6\%) students are male and 238 (60.4\%) are female. Participants are predominantly women.

- 115 (29.2\%) students are preparing for the university exam in Math and Science, 57 (14.5\%) in Social Sciences, 193 (49\%) in Sciences and Social Sciences and 29 (7.4\%) Language type. They are predominantly prepared for Sciences and Social Sciences.

- 174 (44.2\%) have a personal computer, 220 (55.8\%) do not have a personal computer. While half part of the participants have a computer, the other half part does not have a computer for use.

- While 136 (34.5\%) high school students never spent time at the computer, in 201 (55.8\%) students 1-3 hours, 33 (8.4\%) students in 3-5 hours, 14 (3.6\%) Students are between 5-7 hours, 7 students $(1,8 \%)$ are in 7-12 hours, 3 students $(0,8 \%)$ are 12 and more hours. Participants who never spend time at a computer are more than three-quarters of all students. In addition, more than half of the individuals spends 1-3 hours per day.

- While 11 (2.8\%) high school students were not active on the internet at all, 171 students (43.4\%) were active on the internet in 1-3 hours interval, 108 students (27.4\%) were on the internet in 3-5 hours, 51 ( $12.9 \%$ of the students are active in the internet in 5-7 hours, 33 (8.4\%) students are active in the internet in 7-12 
hours, $20(5.1 \%)$ students are active in the internet for 12 and more hours. Nearly half of the participants are active between 1-3 hours on the internet.

- 87 (\% 22,1) high school students' family economic income level is between 01440 TL, 119 (\%30,2) between 1140-2000 TL, 97 (\%24,6) between 2000-3000 TL, 58 (\%14.7) students have a family economic income level between 30004000 TL and 33 (\%8.4) students have a family economic income of 4000 TL and above. Students' family economic income level ranged with more than half of all students 0-1440 TL and 1440-2000 TL.

- $363(92.1 \%)$ of the high school students have an internet connection that can be used continuously in their phones, 31 (7.9\%) does not have internet connection. Almost all of the participants have an internet connection that can be used continuously.

\section{Findings and Interpretations on the Comparison of Digital Literacy Levels of High School Students by their Demographic Characteristics}

The results obtained from the comparison of the digital literacy levels of the students with different variables determined by the researcher are given below.

Table 2.

Findings of High School Students' Digital Literacy Levels by Gender

\begin{tabular}{|c|c|c|c|c|c|c|c|}
\hline Dimension & Gender & $\mathrm{N}$ & $\bar{X}$ & sd & $\mathrm{t}$ & $\mathrm{df}$ & $\mathrm{p}$ \\
\hline \multirow{2}{*}{ Digital Literacy } & Male & 156 & 67,39 & 10,29 & \multirow{2}{*}{4,734} & \multirow{2}{*}{392} & \multirow{2}{*}{, $000^{*}$} \\
\hline & Female & 238 & 62,58 & 9,58 & & & \\
\hline \multirow{2}{*}{ Attitude Dimension } & Male & 156 & 28,00 & 5,01 & \multirow{2}{*}{3,158} & \multirow{2}{*}{392} & \multirow{2}{*}{, $002^{\prime}$} \\
\hline & Female & 238 & 26,43 & 4,68 & & & \\
\hline \multirow{2}{*}{ Technical Dimension } & Male & 156 & 24,28 & 3,93 & \multirow{2}{*}{4,577} & \multirow{2}{*}{392} & \multirow{2}{*}{, $000^{*}$} \\
\hline & Female & 238 & 22,36 & 4,17 & & & \\
\hline \multirow{2}{*}{ Cognitive Dimension } & Male & 156 & 7,60 & 1,66 & \multirow{2}{*}{5,272} & \multirow{2}{*}{392} & \multirow{2}{*}{, $000 *$} \\
\hline & Female & 238 & 6,72 & 1,59 & & & \\
\hline \multirow{2}{*}{ Social Dimension } & Male & 156 & 7,50 & 1,79 & \multirow{2}{*}{2,345} & \multirow{2}{*}{392} & \multirow{2}{*}{,020 } \\
\hline & Female & 238 & 7,06 & 1,86 & & & \\
\hline
\end{tabular}

Digital literacy of high school students participating in the study levels differ according to the gender variable to determine whether to show performed at the independent samples t-test Levene test as a result of equal variance $\left(F_{392}=1.471, p>\right.$ > 05$)$.

Digital literacy dimesion $\left(\mathrm{t}_{392}=4,734, \mathrm{p}<.05\right)$ and attitude sub-dimension $\left(\mathrm{t}_{392}=3,158 ; \mathrm{p}\right.$ $<.05)$, technical sub-dimension ( $\left.\mathrm{t}_{392}=4,577 ; \mathrm{p}<.05\right)$ of high school students participating in the study, cognitive sub-dimension $\left(\mathrm{t}_{392}=5,272 ; \mathrm{p}<.05\right)$ and social sub-dimension 
$\left(t_{392}=2,345 ; p<.05\right)$. Also, the averages of male participants of all means were significantly higher than the average of female participants. Levels of digital literacy, technical, cognitive and social sub-dimensions vary. Digital literacy levels differ according to female and male candidates and it is seen that the average number of female students in all mean is higher than that of male students.

Table 3.

Findings of High School Students' Digital Literacy Levels by Having a Personal Computer

\begin{tabular}{|c|c|c|c|c|c|c|c|}
\hline Dimension & $\begin{array}{l}\text { Having a } \\
\text { Personal } \\
\text { Computer } \\
\text { Status }\end{array}$ & $\mathrm{N}$ & $\bar{X}$ & $\mathrm{sd}$ & $\mathrm{t}$ & $\mathrm{df}$ & $\mathrm{p}$ \\
\hline \multirow{2}{*}{ Digital Literacy } & Yes & 174 & 65,60 & 9,96 & \multirow{2}{*}{1,957} & \multirow{2}{*}{392} & \multirow{2}{*}{,051 } \\
\hline & No & 220 & 63,60 & 10,20 & & & \\
\hline \multirow{2}{*}{$\begin{array}{l}\text { Attitude } \\
\text { Dimension }\end{array}$} & Yes & 174 & 27,41 & 4,85 & \multirow{2}{*}{1,307} & \multirow{2}{*}{392} & \multirow{2}{*}{ 192 } \\
\hline & No & 220 & 26,76 & 4,87 & & & \\
\hline \multirow{2}{*}{$\begin{array}{l}\text { Technical } \\
\text { Dimension }\end{array}$} & Yes & 174 & 23,81 & 4,11 & \multirow{2}{*}{2,913} & \multirow{2}{*}{392} & \multirow{2}{*}{, $004^{*}$} \\
\hline & No & 220 & 22,58 & 4,16 & & & \\
\hline \multirow{2}{*}{$\begin{array}{l}\text { Cognitive } \\
\text { Dimension }\end{array}$} & Yes & 174 & 7,18 & 1,62 & \multirow{2}{*}{1,251} & \multirow{2}{*}{392} & \multirow{2}{*}{,212 } \\
\hline & No & 220 & 6,97 & 1,70 & & & \\
\hline \multirow{2}{*}{ Social Dimension } & Yes & 174 & 7,19 & 1,90 & \multirow{2}{*}{,- 412} & \multirow{2}{*}{392} & \multirow{2}{*}{,680 } \\
\hline & No & 220 & 7,27 & 1,80 & & & \\
\hline
\end{tabular}

In order to determine whether the students' digital literacy levels differed according to whether they had a personal computer or not, independent samples t-test provided the equation of variance as a result of Levene test $\left(F_{392}=0.157, p>.05\right)$.

According to the presence of a personal computer of high school students participating in the research, the digital literacy levels differ in technical dimension dimension $\left(t_{392}=\right.$ $2,193, \mathrm{p}<.05)$. Digital literacy levels of students with personal computers are significantly higher than those of non-personal computer students' digital literacy levels. According to these findings, it can be said that students who have a computer which they can use continuously, have higher level of digital literacy levels in terms of application and computer skills than technical ones. Individuals with computers have come to the fore in the technical dimension. 
Table 4.

Findings of High School Students' Digital Literacy Levels by Having a Mobile Internet Connection

\begin{tabular}{|c|c|c|c|c|c|c|c|}
\hline Dimension & $\begin{array}{l}\text { Having a } \\
\text { Mobile } \\
\text { Internet } \\
\text { Connection } \\
\text { Status }\end{array}$ & $\mathrm{N}$ & $\bar{X}$ & sd & $\mathrm{t}$ & $\mathrm{df}$ & $\mathrm{p}$ \\
\hline \multirow{2}{*}{ Digital Literacy } & Yes & 363 & 64,29 & 10,24 & \multirow{2}{*}{$-1,309$} & \multirow{2}{*}{392} & \multirow{2}{*}{$\begin{array}{l}19 \\
1\end{array}$} \\
\hline & No & 31 & 66,77 & 8,57 & & & \\
\hline \multirow{2}{*}{ Attitude Dimension } & Yes & 363 & 26,95 & 4,94 & \multirow{2}{*}{$-1,359$} & \multirow{2}{*}{392} & 17 \\
\hline & No & 31 & 28,19 & 3,78 & & & 5 \\
\hline \multirow{2}{*}{$\begin{array}{l}\text { Technical } \\
\text { Dimension }\end{array}$} & Yes & 363 & 23,06 & 4,21 & \multirow{2}{*}{,- 988} & \multirow{2}{*}{392} & ,32 \\
\hline & No & 31 & 23,83 & 3,78 & & & 4 \\
\hline \multirow{2}{*}{ Cognitive Dimension } & Yes & 363 & 7,052 & 1,65 & \multirow{2}{*}{,- 759} & \multirow{2}{*}{392} & ,44 \\
\hline & No & 31 & 7,290 & 1,90 & & & 8 \\
\hline \multirow{2}{*}{ Social Dimension } & Yes & 363 & 7,220 & 1,87 & \multirow{2}{*}{,- 504} & \multirow{2}{*}{392} & ,50 \\
\hline & No & 31 & 7,451 & 1,41 & & & 4 \\
\hline
\end{tabular}

Digital literacy of high school students participating in the survey of levels of mobile internet connections according to the variable be performed to determine if they show the independent sample t-test Levene test as a result of the variance could not be provided on equality $\left(\mathrm{F}_{394}=1.633, \mathrm{p}<.05\right)$. According to the status of high school students who have mobile internet connections, digital literacy levels doesn't differ $\left(t_{392}\right.$ $=-1,309 ; \mathrm{p}>$.05). According to the answers given in the research, mobile internet usage is mostly stated as yes. It is also observed that the ones without mobile internet connection are higher than the ones that are average. 
Table 5.

Findings of Digital Literacy Levels of High School Students by the Point Type for University Exam

\begin{tabular}{|c|c|c|c|c|c|}
\hline Dimension & Sum of Square & $\mathrm{df}$ & Mean Square & $\mathrm{F}$ & $\mathrm{p}$ \\
\hline \multirow{2}{*}{ Digital Literacy } & 536,538 & 3 & 178,846 & \multirow{2}{*}{1,751} & \multirow{2}{*}{, 156 } \\
\hline & 39833,922 & 390 & 102,138 & & \\
\hline \multirow{2}{*}{ Attitude Dimension } & 46,871 & 3 & 15,624 & \multirow{2}{*}{ 656 } & \multirow{2}{*}{,579 } \\
\hline & 9283,010 & 390 & 23,803 & & \\
\hline \multirow{2}{*}{ Technical Dimension } & 103,822 & 3 & 34,607 & \multirow{2}{*}{1,995} & \multirow{2}{*}{ 114 } \\
\hline & 6763,833 & 390 & 17,343 & & \\
\hline \multirow{2}{*}{ Cognitive Dimension } & 16,728 & 3 & 5,576 & \multirow{2}{*}{2,004} & \multirow{2}{*}{ 113 } \\
\hline & 1085,282 & 390 & 2,783 & & \\
\hline \multirow{2}{*}{ Social Dimension } & 11,270 & 3 & 3,757 & \multirow{2}{*}{1,103} & \multirow{2}{*}{,348 } \\
\hline & 1328,304 & 390 & 3,406 & & \\
\hline
\end{tabular}

Table 5 shows the results of high school students' digital literacy levels according to the point type prepared for the university exam. The difference between the mean scores of the high school students who participated in the research was not found statistically significant $\left(\mathrm{F}_{393}=24,220 ; \mathrm{p}>.05\right)$. The difference between the scores of the high school students who were prepared for the university in terms of digital literacy, attitude, technical, cognitive and social sub-dimension was not statistically significant.

Table 6.

Findings of High School Students' Digital Literacy Levels by Family Economic Levels

\begin{tabular}{|c|c|c|c|c|c|}
\hline Dimension & Sum of Square & $\mathrm{df}$ & Mean Square & $\mathrm{F}$ & $\mathrm{p}$ \\
\hline \multirow{2}{*}{ Digital Literacy } & 175,866 & 4 & 43,966 & \multirow{2}{*}{,426 } & \multirow{2}{*}{,790 } \\
\hline & 40194,593 & 389 & 103,327 & & \\
\hline \multirow{2}{*}{ Attitude Dimension } & 125,879 & 4 & 31,470 & \multirow{2}{*}{1,330} & \multirow{2}{*}{ 258 } \\
\hline & 9204,002 & 389 & 23,661 & & \\
\hline Technical & 34,130 & 4 & 8,532 & \multirow{2}{*}{,486 } & \multirow{2}{*}{,746 } \\
\hline Dimension & 6833,525 & 389 & 17,567 & & \\
\hline \multirow{2}{*}{$\begin{array}{l}\text { Cognitive } \\
\text { Dimension }\end{array}$} & 6,976 & 4 & 1,744 & \multirow{2}{*}{ 619 } & \multirow{2}{*}{,649 } \\
\hline & 1095,035 & 389 & 2,815 & & \\
\hline \multirow{2}{*}{ Social Dimension } & 5,089 & 4 & 1,272 & \multirow{2}{*}{,371 } & \multirow{2}{*}{,829 } \\
\hline & 1334,484 & 389 & 3,431 & & \\
\hline
\end{tabular}


Table 6 shows the ANOVA in the comparison of literacy levels of high school students according to family economic levels. The difference between the average of family economic levels of high school students was not statistically significant $\left(F_{393}=, 426\right.$; $p>$ .05). It can be said that there is no statistically significant difference between the levels of digital literacy, attitude, technical, cognitive and social sub-dimension of family economic levels of high school students. In addition, it is seen that the students who have high family economic levels doesn't have high levels of digital literacy compared to the individuals with low or low family economic levels.

Table 7.

Findings of Digital Literacy Levels of High School Students' by Time Elapsed on Internet

\begin{tabular}{|c|c|c|c|c|c|}
\hline Dimension & Sum of Square & $\mathrm{df}$ & Mean Square & $\mathrm{F}$ & $\mathrm{p}$ \\
\hline \multirow{2}{*}{ Digital Literacy } & 516,720 & 5 & 103,344 & \multirow{2}{*}{1,006} & \multirow{2}{*}{,414 } \\
\hline & 39853,739 & 388 & 102,716 & & \\
\hline \multirow{2}{*}{ Attitude Dimension } & 62,321 & 5 & 12,464 & \multirow{2}{*}{,522 } & \multirow{2}{*}{ 760 } \\
\hline & 9267,560 & 388 & 23,885 & & \\
\hline Technical & 137,233 & 5 & 27,447 & \multirow{2}{*}{1,582} & \multirow{2}{*}{ 164 } \\
\hline Dimension & 6730,422 & 388 & 17,346 & & \\
\hline \multirow{2}{*}{$\begin{array}{l}\text { Cognitive } \\
\text { Dimension }\end{array}$} & 7,230 & 5 & 1,446 & \multirow{2}{*}{,512 } & \multirow{2}{*}{ 767 } \\
\hline & 1094,781 & 388 & 2,822 & & \\
\hline \multirow{2}{*}{ Social Dimension } & 15,942 & 5 & 3,188 & \multirow{2}{*}{,935 } & \multirow{2}{*}{,458 } \\
\hline & 1323,632 & 388 & 3,411 & & \\
\hline
\end{tabular}

Tablo 7 shows that ANOVA test was applied because it had a variable and multiple subdimension because of its normal distribution ( $p>.05$ ). The difference between the digital literacy, attitude, technical, cognitive and social sub-dimension mean scores of high school students participating in the research were not found statistically significant. (p>.05*) 
Table 8.

Findings of Digital Literacy Levels of High School Students' by Time Elapsed on Personal Computer

\begin{tabular}{|c|c|c|c|c|c|c|}
\hline Dimension & $\begin{array}{l}\text { Sum of } \\
\text { Square }\end{array}$ & $\mathrm{df}$ & Mean Square & $\mathrm{F}$ & $\mathrm{p}$ & Significance \\
\hline Digital & 985,344 & 5 & 197,069 & \multirow{2}{*}{1,941} & \multirow{2}{*}{,087 } & \\
\hline Literacy & 39385,115 & 388 & 101,508 & & & \\
\hline \multirow{2}{*}{$\begin{array}{l}\text { Attitude } \\
\text { Dimension }\end{array}$} & 63,891 & 5 & 12,778 & \multirow{2}{*}{,535 } & \multirow{2}{*}{,750 } & \\
\hline & 9265,989 & 388 & 23,881 & & & \\
\hline \multirow{5}{*}{$\begin{array}{l}\text { Technical } \\
\text { Dimension }\end{array}$} & \multirow{5}{*}{$\begin{array}{l}267,768 \\
6599,887\end{array}$} & \multirow{5}{*}{$\begin{array}{l}5 \\
388\end{array}$} & \multirow{5}{*}{$\begin{array}{l}53,554 \\
17,010\end{array}$} & \multirow{5}{*}{3,148} & \multirow{5}{*}{, $008^{*}$} & $\mathrm{E}>\mathrm{A}, \mathrm{B}, \mathrm{C}, \mathrm{D}, \mathrm{F}$ \\
\hline & & & & & & $\mathrm{C}>\mathrm{A}, \mathrm{B}, \mathrm{D}, \mathrm{F}$ \\
\hline & & & & & & $\mathrm{D}>\mathrm{A}, \mathrm{B}, \mathrm{F}$ \\
\hline & & & & & & $\mathrm{B}>\mathrm{A}, \mathrm{F}$ \\
\hline & & & & & & $A>F$ \\
\hline \multirow{5}{*}{$\begin{array}{l}\text { Cognitive } \\
\text { Dimension }\end{array}$} & \multirow{5}{*}{$\begin{array}{l}31,395 \\
1070,615\end{array}$} & \multirow{5}{*}{$\begin{array}{l}5 \\
388\end{array}$} & \multirow{5}{*}{$\begin{array}{l}6,279 \\
2,759\end{array}$} & \multirow{5}{*}{2,276} & \multirow{5}{*}{, $047^{*}$} & $E>A, B, C, D, F$ \\
\hline & & & & & & $\mathrm{F}>\mathrm{A}, \mathrm{B}, \mathrm{C}, \mathrm{D}$ \\
\hline & & & & & & $\mathrm{D}>\mathrm{A}, \mathrm{B}, \mathrm{C}$ \\
\hline & & & & & & $B>A, C$ \\
\hline & & & & & & $\mathrm{C}>\mathrm{A}$ \\
\hline \multirow{5}{*}{$\begin{array}{l}\text { Social } \\
\text { Dimension }\end{array}$} & \multirow{5}{*}{$\begin{array}{l}48,789 \\
1290,785\end{array}$} & \multirow{5}{*}{$\begin{array}{l}5 \\
388\end{array}$} & \multirow{5}{*}{$\begin{array}{l}9,758 \\
3,327\end{array}$} & \multirow{5}{*}{2,933} & \multirow{5}{*}{,013* } & $E>A, B, C, D, F$ \\
\hline & & & & & & $\mathrm{B}>\mathrm{A}, \mathrm{C}, \mathrm{D}, \mathrm{F}$ \\
\hline & & & & & & $\mathrm{D}>\mathrm{A}, \mathrm{C}, \mathrm{F}$ \\
\hline & & & & & & $\mathrm{A}>\mathrm{C}, \mathrm{F}$ \\
\hline & & & & & & $\mathrm{C}>\mathrm{F}$ \\
\hline
\end{tabular}

In Table 8, the difference between the mean scores of the high school students and the technical sub-dimensions of the students were statistically significant. According to this, it is seen that there is a significant difference in technical, cognitive and social dimensions according to the time period of the computer. $\left(F_{393}=3.1148 ; \mathrm{p}<.05 *\right)$.

In order to make the tables more understandable, it indicated as none (A), 1-3 Hours (B), 3-5 Hours (C), 5-7 Hours (D), 7-12 Hours (E), 12 hours and above (F). After the ANOVA test, post-hoc analyzes were performed to determine which groups had significant differences.

The level of digital literacy among the students using computer in the 7-12 hour interval is significantly different in technical, cognitive and social dimensions. In other words, as the time spent on the computer increased, it was found that the usage of computer skills, processing of information and social level of it were statistically higher than the other students. 


\section{DISCUSSION, CONCLUSIONS AND SUGGESTIONS}

\section{Results}

The aim of this study is to determine the levels of digital literacy among high school students studying at 10th grade and to investigate the relationship between the various variables. The study group of the study was conducted voluntarily with 5 schools in the district of Hendek in Sakarya province. The scale was adapted by the researchers used in research period and shaped according to the sub-dimensions of the digital literacy scale. These dimensions; attitudes, technical, cognitive and social sub-dimensions. Independent samples t-Test was applied for high school students' gender, continuous mobile Internet connection status, personal computer status, internet and computer usage variables. One-way variance test was applied to determine the high school students prepared for the university exam and the family economic income levels, the time spent active on the internet and the time spent on the computer. Based on the data obtained, the results are as follows. The results are given below.

When the researches about the research subject are examined, it is seen that the level of digital literacy varies according to the gender variable. The results obtained according to the gender variable in the research support the relevant research (Kıyıcl, 2008; Yıldız, Kahyaoğlu and Kaya, 2012; Kazu and Erten, 2014; Çetin, 2016).

The digital literacy level of the students participating in the research shows that there is a significant difference in the technical dimension. At the same time, it is concluded that the availability of personal computers that they can use continuously is more differentiated in technical dimension and differentiated according to the applicationoriented activities. In the Kıyıcı (2008) also, digital literacy levels showed a significant difference in their study according to the computer situation they could use continuously.

It has been concluded that digital literacy levels don't differ in any sub-dimension according to a mobile internet connection they can use continuously and according to the type of score they are preparing for university. There is no study that supports or does not support the research by measuring the different dimensions of the scale used in the researches. It was concluded that digital literacy levels did not differ in any subdimension according to family income levels. There is no study that supports or does not support the research by measuring the different dimensions of the scale used in the researches.

As a result of the analyzes, it was found that the digital literacy levels participating in the study did not differ in any sub-dimension according to the duration of active activity on the internet, but the results were significant in terms of technical, cognitive and social dimensions. According to researches in literature, there is a significant difference according to whether there is internet connection (Kıyıcl, 2008). However, in terms of active time, Çetin (2016) concluded that the frequency of internet use has an effect on the levels of digital literacy. The research is supported by a significant difference in the technical, cognitive and social dimensions. 


\section{Discussion}

It is tried to reveal whether the variables of digital literacy differ according to these variables by adding different independent variables to the studies related to digital literacy. The digital literacy scale developed by $\mathrm{Ng}$ (2012) and adapted from Hamutoğlu, Güngören, Uyanık and Erdoğan (2017), has led to a different dimension in determining the digital literacy levels of the participants. It differs from the others in terms of the scale used in the study and also with the addition of different demographic features. According to the research results, some of the independent variables used in the research support other studies, while others do not. The different demographic characteristics identified in the study are an impressive function in the emergence of this difference.

Gender-related results were also supported by previous studies. In contrast to the gender variable, the state of having computers and the active time variables spent on the computer were included in the research process in order to present a new perspective to the research of the literature. The fact that the time spent at the computer is different in most of the sub-dimensions and what the participants do in terms of digital literacy and what functions they usually devote to the generalities are important for evaluating the effect of this variable on digital literacy. Not only the time spent on the computer, but also on the availability of a computer that they can use consistently differed according to their level of digital literacy. The results show that both of these variables differ significantly in technical dimension. It is aimed to gain a different perspective on future research.

\section{Suggestions}

A number of suggestions for the implementation of the results of the study were expressed. These are:

- Research can be developed with different samples in different provinces.

- In the results obtained, it was determined that the digital literacy level of the individuals who participated in the study varied according to the gender variable. In this context, digital literacy trainings and certificate programs can be opened for students.

- It can be added to the curriculum as an elective course within the scope of the digital literacy and competence development program for students studying in this field.

- In order to comply with the ethical rules of internet, trainings can be given to conduct scientific research within the scope of digital literacy. 
- Students who do not have a computer and do not have an internet connection to develop their digital literacy skills can be given the freedom to use laboratories free of charge during the day at the school they study.

- Digital literacy can be promoted as the totality of skills required for each individual.

Turkey can be added to the university lecturer of courses free of charge throughout the internet. 


\section{References}

Adams, M. J. (1993). Beginning to read: Learning and Thinking about Print. London: Hodder \& Stoughton.

Akkoyunlu, B., \& Soylu, Y. (2010). Öğretmenlerin Sayısal Yetkinlikleri Üzerine Bir Çalışma. Türk Kütüphaneciliği Dergisi, 24(4), 748-768.

Altun, A. (2008). Gelişen Teknolojiler ve Yeni Okuryazarlıklar. İlköğretmen Eğitimci Dergisi, 2034.

Appel, M. (2012). Are Heavy Users of Computer Games and Social Media More Computer Literate? Computers \& Education, 59(4), 1339-1349.

Aviram, A., \& Eshet-Alkalai, Y. (2006). Towards a Theory of Digital Literacy: Three Scenarios for the Next $\quad$ Steps. $11 \quad$ Mart 2017 tarihinde http://www.eurodl.org/materials/contrib/2006/Aharon Aviram.htm adresinden erişildi.

Büyüköztürk, Ş., Akgün, Ö. E., Karadeniz, Ş., Demirel, F., \& Çakmak, E. K. (2017). Bilimsel Araştırma Yöntemleri. Ankara: Pegem Akademi Yayıncllık.

Cope, B., \& Kalantzis, M. (2000). Multiliteracies: Literacy Learning And The Design Of Social Futures. London: Routledge.

Cumhuriyet. (2017, Eylül 3). Türkiye'de akıllı telefon kullanım oranı. http://www.cumhuriyet.com.tr/haber/ekonomi/816129/iste_Turkiye de_akilli telefon kulla nim orani.html adresinden erişildi.

Çetin, O. (2016). Pedagojik Formasyon Programı ile Lisans Eğitimi Fen Bilimleri Öğretmen Adaylarının Dijital Okuryazarlık Düzeylerinin İncelenmesi. Erzincan Üniversitesi Ĕgitim Fakültesi Dergisi, 18(2), 658-685.

Eshet-Alkalai, Y. (2002). Digital Literacy: A New Terminology Framework and Its Application to The Design of Meaningful Technology-Based Learning Environments. EDMEDIA, p. 493-498. https://eric.ed.gov/?id=ED477005 adresinden erişildi.

Eshet-Alkalai, Y. (2004). Digital Literacy: A Conceptual Framework for Survival Skills in The Digital Era. Journal of Educational Multimedia and Hypermedia, 139(1), 93-106.

Evering, L., \& Moorman, G. (2012). Rethinking Plagiarism in the Digital Age. Journal of Adolescent \& Adult Literacy International Reading Association, 56(1), 35-44.

Fransman, J. (2006). Understanding Literacy: A Concept Paper. Paris: UNESCO Publishing.

Future Lab. (2010). Digital Literacy Across The Curriculum. 19 Kasım 2017 https://www.nfer.ac.uk/publications/FUTL06/FUTL06.pdf adresinden alındı.

Gilster, P. (1997). Digital Literacy. New York: Wiley Publishing.

Hagel, P., Horn, A., Owen, S., \& Currie, M. (2013). 'How Can We Help?' The Contribution of University Libraries to Student Retention. Australian Academic \& Research Libraries, 4(3), 214-230.

Hamutoglu, N. B., Güngören-Canan, Ö., Kaya-Uyanık, G. \& Gür-Erdoğan, D. (2017). Dijital Okuryazarlık Ölçeği: Türkçe 'ye uyarlama çalışması. Ege Eğitim Dergisi, 18(1), 408- 429.

Herkese Bilim ve Teknoloji. (2017, Haziran 8). Herkese Bilim ve Teknoloji: https://www.herkesebilimteknoloji.com/haberler/teknoyasam/internetin-babasi-timberners-lee adresinden alındı. 
Jones-Kavalier, B., \& Flannigan, S. (2006). Connecting the Digital Dots: Literacy of the 21st Century. Educase Quarterly, 29(2), 1-3.

Kıyıcı, M. (2008). Öğretmen Adaylarının Sayısal Okuryazarlık Düzeylerinin Belirlenmesi. Yayımlanmamış Doktora Tezi. Anadolu Üniversitesi, Eğitim Bilimleri Enstitüsü.

Kazu, İ. Y., \& Erten, P. (2013). Prospective Teachers' Perception Levels of Their Digital Literacy. International Journal of Multidisciplinary Thought, 3(1), 51-68.

Köklü, N., Büyüköztürk, Ş., \& Çokluk-Bökeoğlu, Ö. (2007). Sosyal bilimler için istatistik. Pegem A Yayıncilık.

Lankshear, C., \& Knobel, M. (2006). Discussing new literacies. Language Arts, 84(1), 78-86.

Ng, W. (2012). Why Digital Literacy is Important for Science Teaching and Learning. Curriculum \& Leadership Journal, 10, 7-12.

Oblinger, D. (2005). Learners, Learning and Technology: The EDUCAUSE Learning Initiative. Educaus Review, 40(5), 66-75.

Palfrey, J., \& Gasser, U. (2008). Born Digital Understanding First Generation of Digital Natives. New York: Basic Books.

Prensky, M. (2001). Digital Natives Digital Immigrants. On the Horizon, 9(5), 1-6.

Rimer, S. (2003). A Campus Fad That's Being Copied: Internet Plagiarism Seems on the Rise, The New York Times.

Sharma, R., Fantin A., Prabhu, N., Guan C., \& Dattakumar, A. (2016). Digital literacy and knowledge societies: A grounded theory investigation of sustainable development. Telecommunications Policy, 40(7), 628-643.

Street, B. V. (2006). Understanding and Defining Literacy. Background Paper Prepared for the Education for All Global Monitoring Report. Paris: UNESCO.

T.C Milli Eğitim Bakanlığı. (2007). 2008 Yılı Bütçesine İlişkin Rapor. Ankara: Devlet Kitapları Müdürlüğü Basımevi.

T.C. Milli Eğitim Bakanlığı. (2008). 2009 Yılı Bütçesine İlişkin Rapor. Ankara: Devlet Kitapları Müdürlüğü Basımevi.

T.C. Milli Eğitim Bakanlığı. (2009). 2010 Yılı Bütçesine İlişkin Rapor. Ankara: Devlet Kitapları Müdürlüğü Basımevi.

Tabachnick, B. G., \& Fidell, S. L. (2013). Using Multivariate Statistics (sixth ed.). Boston: Pearson.

Tornero, J. M. (2004). Promoting Digital Literacy. Understanding Digital Literacy. Barcelona: Unión Europea: Educación y Cultura. http://www.pedz.uni-mannheim.de/daten/edzb/gdbk/04/dig_lit_en.pdf adresinden erişildi.

UNESCO. (1970). Literacy 1967-1969. Progress Achieved in Literacy Throughout the World. Paris: UNESCO. 10 Şubat 2017 http://unesdoc.unesco.org/images/0003/000372/037284eo.pdf adresinden tarihinde erişildi.

Yıldız, Ç., Kahyaoğlu, M., \& Kaya, F. (2012). Siirt İlindeki Ortaöğretim Öğrencilerinin Sayısal Okuryazarlık Düzeylerinin Cinsiyet, Sınıf ve Öğrenim Gördüğü Lise Türüne Göre Farklılaşmasının İncelenmesi. Uşak Üniversitesi Sosyal Bilimler Dergisi, 5(3), 82-96 